\title{
Analisis Penerapan InternetFinancial Reporting (IFR) pada Bank Umum Syariah di Indonesia
}

\author{
Muhammad Iqbal Muttaqin \\ Program Studi Akuntansi Syariab/STEI SEBI, \\ Email: iqbalmuttaqin849@gmail.com \\ Ahmad Baehaqi \\ Program Studi Akuntansi Syariab/STEI SEBI, \\ Email:abmad.baehaqi@sebi.ac.id \\ Roni Hidayat \\ STEI SEBI dan UIN Syarif Hidayatullah Jakarta, \\ Email: ronibidayat.ma@gmail.com
}

\begin{abstract}
:
This study aims to analyze the practice of IFR on BUS in Indonesia. This research use a scoring technique. The research data obtained from the official website of each BUS in the form of financial and non-financial information observed in 2020. The results of this study indicate that on average BUS has succeeded in revealing variable content quite broadly. 10 from 13 banks or $77 \%$ of the research samples have succeded in presenting disclosure items with a score $70 \%-79.9 \%$. While the rest get a score $60 \%-69.9 \%$. There are 8 BUS that can maintain and improve their scores in this variable. The first rank in display variable was achieved by BNIS with a score of $75 \%$ or equivalent to 15 of the 20 disclosure items tested. Meanwhile, the average BUS has used more than $50 \%$ of the indicator display items tested. However, there are still two BUS that use display indicator items below 50\%, namely BSMI and BCAS with a score of $45 \%$. For the timeliness variable showed unsatisfactory results. Where the largest score obtained by BRIS with a score reaching $36 \%$. While the rest, only able to disclose of timeliness indicators between $9 \%-27 \%$.

Penelitian ini bertujuan untuk menganalisis praktik IFR pada BUS di Indonesia. Penelitian ini menggunakan teknik scoring. Data penelitian didapatkan dari website resmi masing-masing BUS berupa keterangan/informasi keuangan dan nonkeuangan yang diamati pada tahun 2020. Hasil dari penelitian ini menunjukkan bahwa rata-rata BUS telah berhasil mengungkapkan variabel isi dengan cukup luas. Diketahui, 10 dari 13 bank atau 77\% dari sampel penelitian telah berhasil menyajikan item pengungkapan dengan skor $70 \%$ - 79,9\%. Sementara sisanya mendapatkan skor sebesar $60 \%$ $69.9 \%$. Kurang lebih ada 8 BUS yang berhasil mempertahankan dan meningkatkan skornya dalam variabel ini. Sedangkan untuk variabel tampilan, peringkat pertama diraih oleh BNIS dengan skor $75 \%$ atau setara dengan 15 dari 20 item pengungkapan yang diujikan. Sementara, rata-rata BUS telah menggunakan lebih dari 50\% item indikator tampilan yang diujikan. Tetapi, masih ada dua BUS yang menggunakan item indikator tampilan di bawah 50\%, yaitu BSMI dan BCAS dengan skor $45 \%$. Untuk variabel ketepatwaktuan menunjukkan hasil yang kurang memuaskan. Dimana skor terbesar didapatkan oleh BRIS dengan skor mencapai 36\%. Sementara sisanya, hanya mampu mengungkapkan item indikator ketepatwaktuan berkisar antara 9\% - 27\%.]
\end{abstract}

Kata Kunci: Internet Financial Reporting (IFR); Pengungkapan; Bank Umum Syariah 


\section{PENDAHULUAN}

Era digital dan industri 4.0 merupakan fase dimana internet berkembang begitu pesat, terlebih dalam perkembangan teknologi informasi. Kehadiran internet kini merubah pola hidup masyarakat tradisional menjadi masyarakat modern. Perusahaan turut ikut serta dalam perkembangan teknologinya. Ketika internet menyebabkan evolusi laporan keuangan dengan desain konvensional dalam bentuk laporan tahunan cetak

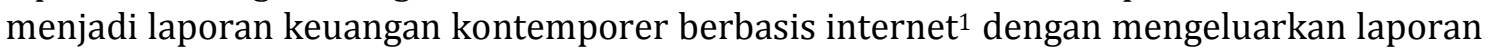
keuangan maupun laporan kinerja perusahaan dalam website perusahaan.

Internet mempunyai banyak kelebihan yang bisa menguntungkan bagi perusahaan. Internet dapat menjadi sebuah media dalam menyampaikan informasi yang penting karena memiliki berbagai keunggulan seperti mudah menyebar (pervasiveness), tidak mengenal batas (borderless-ness), real-time, berbiaya rendah (low cost), dan mempunyai interaksi yang tinggi (high interaction) serta diintegrasi dengan teks, angka, gambar, animasi, video dan suara. ${ }^{2}$ Menempatkan informasi pada website perusahaan dapat memudahkan pengguna informasi dalam mencari berbagai informasi yang dibutuhkan terkait perusahaan tanpa mengeluarkan biaya yang cukup tinggi. ${ }^{3}$

Bentuk penyajian laporan keuangan melalui website ini dikenal dengan sebutan Internet Financial Reporting (IFR). Pelaporan dari IFR ini sendiri mengungkapkan beberapa laporan keuangan melalui penggunaan teknologi seperti multimedia dan alat website analisis. ${ }^{4}$ Berdasarkan data yang diperoleh dari Internet World Stats (2019) Asia menempati urutan teratas dalam penggunaan internet di dunia. Dalam hal ini, Asia mengambil porsi yang cukup besar dengan nilai pesentase sebesar 50.7\% dengan perbedaan yang cukup jauh dengan posisi kedua yang ditempati oleh Eropa dengan perolehan persentase sebesar $16 \%$. Di Indonesia sendiri, jumlah pengguna internet per Juni 2019 adalah sebesar 171 juta jiwa atau setara dengan $7.4 \%$ dari total pengguna internet di kawasan Asia.

Secara konstitusional, peraturan terkait IFR atau pelaporan keuangan melalui internet di Indonesia telah diatur dalam keputusan ketua Badan Pengawas Pasar Modal dan Lembaga Keuangan (BAPEPAM-LK) Nomor Kep-431/BL/2012 Pasal 3 yang menyatakan bahwa emiten atau perusahaan publik yang telah memiliki halaman website sebelum berlakunya peraturan ini wajib memuat laporan tahunan di halaman website. Dalam jangka waktu 1 (satu) tahun sejak diberlakukannya peraturan ini, perusahaan publik wajib memiliki halaman website dengan memuat laporan tahunan. Peraturan terkait tata cara penyampaian laporan keuangan secara elektronik oleh emiten atau

\footnotetext{
1 Andrew Munthopa Lipunga, "Internet Financial Reporting in Malawi," International Journal of Business and Management 9, no. 6 (2014).

${ }^{2}$ I Made Narsa and Fitri Fenti Pratiwi, "Internet Financial Reporting, Pengungkapan Informasi Website , Luas Lingkup Pelaporan Internet, Dan Nilai Perusahaan," Jurnal Ekonomi Dan Keuangan 18, no. 80 (2014), https://doi.org/10.24034/j25485024.y2014.v18.i2.152.

3 Luciana Spica Almilia, "Faktor-Faktor Yang Mempengaruhi Pengungkapan Sukarela 'Internet Financial and Sustainability Reporting,"' Jurnal Akuntansi Dan Auditing Indonesia 12, no. 2 (2008).

${ }^{4}$ Lizzcharly Purba et al., "Internet Financial Reporting Index Analysis: An Overview from the State Owned Enterprises in Indonesia," Journal of Economics, Business and Management 1, no. 3 (2013). 66 Iqtishadia: Jurnal Ekonomi dan Perbankan Syariah 
Analisis Penerapan Internet Financial Reporting

(IFR) pada Bank Umum Syariah di Indonesia

perusahaan publik juga diatur dalam surat edaran OJK Nomor 6/SEOJK.04/2014 Tahun 2014.5

Pengungkapan informasi keuangan melalui website dapat mengurangi terjadinya ketimpangan informasi antara pihak perusahaan dengan pihak investor maupun kreditur. Selain itu, dengan penerapan IFR maka perusahaan dapat memenuhi tanggung jawabnya kepada masyarakat umum. Hal ini sesuai dengan teori stakeholder yang mengasumsikan bahwa perusahaan memiliki lingkup tanggung jawab yang luas. Perusahaan harus membuat berbagai keputusan dengan mempertimbangkan kepentingan semua pihak dalam perusahaan (tidak hanya penuntut keuangan, tetapi juga karyawan, pelanggan, masyarakat dan pejabat pemerintah). ${ }^{6}$ Oleh karena itu, penggunaan IFR dalam suatu perusahaan sangatlah penting, karena dampaknya mencakup investor, kreditur dan masyarakat luas.

Berdasarkan data yang diperoleh diketahui bahwa nasabah Bank Umum Syariah terus mengalami peningkatan setiap tahunnya. ${ }^{7}$ Dengan adanya peningkatan tersebut maka sangat disayangkan apabila Bank Umum Syariah tidak menerapkan praktik IFR ini secara maksimal. Mengingat banyaknya keunggulan yang ditawarkan IFR seperti dapat mempromosikan perusahaan lebih luas kepada publik, memberikan cakupan lebih luas, menarik pelanggan potensial, menyediakan aksesibilitas kepada pengguna, membantu pengguna dalam proses pengambilan keputusan dan lain sebagainya. ${ }^{8}$

Ini juga berlaku bagi industri perbankan syariah sebagai lembaga fidusia yang memiliki tanggung jawab penuh terhadap masyarakat secara signifikan. Kewajiban mengenai transparansi tersebut terkandung dalam Peraturan Bank Indonesia Nomor 11/33/PBI/2009 tentang pelaksanaan Good Corporate Governance bagi Bank Umum Syariah dan Unit Usaha Syariah yang menyatakan bahwa perbankan syariah wajib untuk melaksanakan transparansi kondisi keuangan dan non-keuangan kepada stakeholders. Sebagai upaya pemenuhan salah satu prinsip Good Corporate Governance itu sendiri yaitu transparansi atau keterbukaan. ${ }^{9}$

Selain melihat Peraturan Bank Indonesia (PBI) di atas, industri perbankan syariah mempunyai tanggung jawab lebih dalam melakukan prinsip transparansi. Sebagai lembaga keuangan syariah, maka perbankan syariah juga dituntut untuk dapat memenuhi kepatuhan syariah dalam menjalankan aktifitas operasionalnya. Hal ini termuat dalam Pasal 2 Peraturan Bank Indonesia Nomor 10/16/PBI/2008 tentang Perubahan atas Peraturan Bank Indonesia Nomor 9/19/PBI/2007 tentang Pelaksanaan Prinsip Syariah

\footnotetext{
5 Ilham Maulana Saud, Bustanul Ashar, and Peni Nugraheni, "Analisis Pengungkapan Internet Financial Reporting Perusahaan Asuransi-Perbankan Syariah Di Indonesia-Malaysia," Jurnal Media Riset Akuntansi, Auditing \& Informasi 19, no. 1 (2019), https://doi.org/10.25105/mraai.v19i1.3011. 6 Michael C. Jensen, "Value Maximisation, Stakeholder Theory, and The Corporate Objective Function," Journal of Applied Corporate Finance 14, no. 3 (2001), https://doi.org/10.1111/1468036X.00158.

${ }^{7}$ Otoritas Jasa Keuangan, “Statistik Perbankan Syariah,” 2019.

8 Mohd Noor Azli Ali Khan and Noor Azizi Ismail, "Users' Perceptions of Various Aspects of Malaysian Internet Financial Reporting," Journal of Organizational Management Studies 2012 (2012), https://doi.org/10.5171/2012.852558.

${ }_{9}$ Ria Nur Rizqiyah and Ahmad Tarmizi Lubis, "Penerapan Internet Financial Reporting (IFR) Pada Bank Umum Syariah Di Indonesia," Jurnal Akuntansi Dan Keuangan Islam 5, no. 1 (2017), https://doi.org/10.35836/jakis.v5i1.14.
}

Iqtishadia: Jurnal Ekonomi dan Perbankan Syariah 
dalam Kegiatan Penghimpunan Dana dan Penyaluran Dana serta Pelayanan Jasa Bank Syariah

Semakin tinggi IFR suatu Bank Umum Syariah, maka asimetri informasi yang terjadi di antara para pihak yang berkepentingan semakin menurun. Dengan menurunnya asimetri informasi tersebut akan meningkatkan kepercayaan para pemangku kepentingan kepada manajemen Bank Umum Syariah. Dengan demikian, maka akan lebih banyak lagi pokok-pokok nilai yang harus diungkapkan dalam melaksanakan transparansi tersebut. ${ }^{10}$

Walaupun praktik IFR telah berkembang pesat dan menawarkan begitu banyak manfaat yang dapat diperoleh oleh perusahaan, namun masih banyak dari sejumlah perusahaan yang tidak menerapkannya. ${ }^{11}$ Selain itu penelitian mengenai komparasi indeks IFR pada website perusahaan go public di Indonesia juga menemukan bahwa $62 \%$ perusahaan sudah mempunyai website namun sebagian besar perusahaan belum mampu memanfaatkan sarana yang tersedia di website tersebut secara optimal baik untuk informasi keuangan dan keberlanjutan perusahaan. Meskipun perusahaan-perusahaan tersebut termasuk kedalam industri perbankan yang merupakan industri dengan regulasi yang ketat. ${ }^{2}$

Penelitian lain menemukan bahwa sebagian besar BUS belum memaksimalkan penggunaan media website dalam menyajikan laporan keuangan yang interaktif. Sebagian besar BUS hanya menyajikan laporan publikasinya dengan format pdf yang terlihat sama seperti laporan keuangan cetak. ${ }^{13}$ Dalam penelitian terkait penerapan IFR antara bank syariah yang berada di Indonesia dan Malaysia juga menemukan bahwa beberapa bank syariah di Indonesia dan Malaysia masih ada yang belum maksimal dalam menerapkan IFR dengan asumsi dikarenakan penerapan IFR ini sifatnya masih sukarela. ${ }^{14}$ Penelitian Pertiwi menghasilkan suatu simpulan bahwa tidak ada perbedaan yang berarti antara indeks IFR bank syariah Indonesia dan Malaysia.

Penelitian yang dilakukan tentang studi komparasi IFR pada Bank Umum Syariah di Indonesia dan Malaysia menujukkan bahwa terdapat perbedaan yang signifikan terhadap kualitas IFR antara Indonesia dan Malaysia. Berdasarkan pengujian hipotesis, Bank Umum Syariah di Indonesia lebih baik dalam pengungkapan laporan keuangan menggunakan media internet. ${ }^{15}$ Selanjutnya penelitian tentang penerapan IFR pada BUS di Indonesia menunjukkan bahwa BNI Syariah berada pada peringkat pertama dengan skor IFR sebesar $63 \%$ atau setara dengan mengungkapkan 70 dari 112 item yang

\footnotetext{
10 Taqiyah Dinda Insani and Noven Suprayogi, "Internet Financial Reporting: Studi Komparasi Bank Umum Syariah Di Indonesia Dan Malaysia," Jurnal Ekonomi Syariah Teori Dan Terapan 3 (2016), https://doi.org/10.20473/vol3iss201611pp886.

${ }^{11}$ Purba et al., "Internet Financial Reporting Index Analysis: An Overview from the State Owned Enterprises in Indonesia."

12 Luciana Spica Almilia, "Analisa Komparasi Indeks Internet Financial Reporting Pada Website Perusahaan Go Publik Di Indonesia," Seminar Nasional Aplikasi Teknologi Informasi 2009, 2009.

${ }^{13}$ Rizqiyah and Lubis, "Penerapan Internet Financial Reporting (IFR) Pada Bank Umum Syariah Di Indonesia."

${ }^{14}$ Imanda Firmantyas Putri Pertiwi, "Kinerja Keuangan Dan Internet Financial Reporting Index (IFRI): Sebuah Studi Relevansi Pada Sektor Perbankan Syariah Di Kawasan ASEAN," Jurnal Ekonomi \& Perbankan Syariah 4, no. 1 (2017), https://doi.org/10.19105/iqtishadia.v4i1.1221.

${ }^{15}$ Insani and Suprayogi, "Internet Financial Reporting: Studi Komparasi Bank Umum Syariah Di Indonesia Dan Malaysia." 
Analisis Penerapan Internet Financial Reporting

(IFR) pada Bank Umum Syariah di Indonesia

diujikan, diikuti BSM, BRIS dan Bank Panin. Kesebelas BUS yang dijadikan sampel penelitian dinyatakan sudah bisa melaksanakan IFR dengan hasil skor IFR keseluruhan sebesar 55\% (62,09item) dengan distribusi skor IFR masing-masing BUS yang tidak jauh berbeda, yakni berkisar mulai dari $49 \%$ hingga $63 \% .^{16}$

Berdasarkan pemaparan di atas dan beberapa hasil penelitian terdahulu, maka peneliti tertarik untuk mengkaji kembali terkait pelaksanaan IFR pada Bank Umum Syariah dengan judul "Analisis Penerapan Internet Financial Reporting (IFR) pada Bank Umum Syariah di Indonesia”. Berbeda dengan penelitian sebelumnya yang hanya melakukan analisis IFR pada tahun 2015 dengan jumlah $11 \mathrm{BUS},{ }^{17}$ dalam penelitian ini akan diungkap penerapan IFR dengan periode penelitian lebih panjang selama 3 tahun, yakni pada tahun 2016, 2017 dan 2018 untuk melihat perbandingan serta perkembangan penerapan IFR setiap periodenya, dengan Objek penelitian berjumlah 13 BUS. Selain itu, saat ini BUS juga telah terikat oleh Peraturan Otoritas Jasa Keuangan Nomor 32/POJK.03/2016 tentang Peruhahan Atas Peraturan Otoritas Jasa Keuangan Nomor 6/POJK.03/2015 tentang Transparansi dan Publikasi Laporan Bank yang mewajibkan BUS untuk mempublikasikan laporan keuangannya melalui situs web resmi yang dimilikinya sehingga pada penelitian ini akan dilakukan pula pengamatan khusus untuk melihat bagaimana BUS melaksanakan peraturan tersebut.

\section{METODE PENELITIAN}

Metode yang digunakan dalam penelitian ini adalah metode penelitian kualitatif dengan pendekatan deskriptif. Variabel yang digunakan untuk menilai penerapan praktik IFR pada penelitian ini terdiri dari tiga bagian, yaitu variabel isi (content), tampilan (presentation) dan ketepatwaktuan (timelinessy). Variabel ini merupakan modifikasi dan penggabungan dari beberapa variabel yang biasa digunakan dalam penelitian IFR. Untuk lebih jelasnya dapat dilihat pada tabel 1.

Tabel 1. Item Indikator Pengungkapan IFR

\begin{tabular}{|c|c|}
\hline Variabel & Item yang diungkapkan pada website BUS \\
\hline \multirow{6}{*}{ 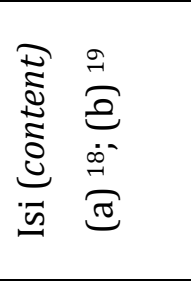 } & Laporan posisi keuangan tahun berjalan (a) \\
\hline & 2 Laporan laba rugi komprehensif tahun berjalan (a) \\
\hline & 3 Laporan perubahan ekuitas tahun berjalan (a) \\
\hline & $4 \quad$ Laporan arus kas tahun berjalan (a) \\
\hline & $5 \quad$ Catatan atas laporan keuangan tahun berjalan (a) \\
\hline & 6 Laporan komitmen dan kontinjensi tahun berjalan (a) \\
\hline
\end{tabular}

\footnotetext{
16 Rizqiyah and Lubis, "Penerapan Internet Financial Reporting (IFR) Pada Bank Umum Syariah Di Indonesia."

17 Ibid.

18 Otoritas Jasa Keuangan, "Salinan Surat Edaran Otoritas Jasa Keuangan Nomor 18/SEOJK.03/2015 Tentang Transparansi Dan Publikasi Laporan Bank Umum Syariah Dan Unit Usaha Syariah," 2015.

19 Mohd Noor Azli Ali Khan and Noor Azizi Ismail, "The Level of Internet Financial Reporting of Malaysian Companies," Asian Journal of Accounting and Governance 2, no. 1 (2011), https://doi.org/10.17576/ajag-2011-2-6539.
}

Iqtishadia: Jurnal Ekonomi dan Perbankan Syariah 


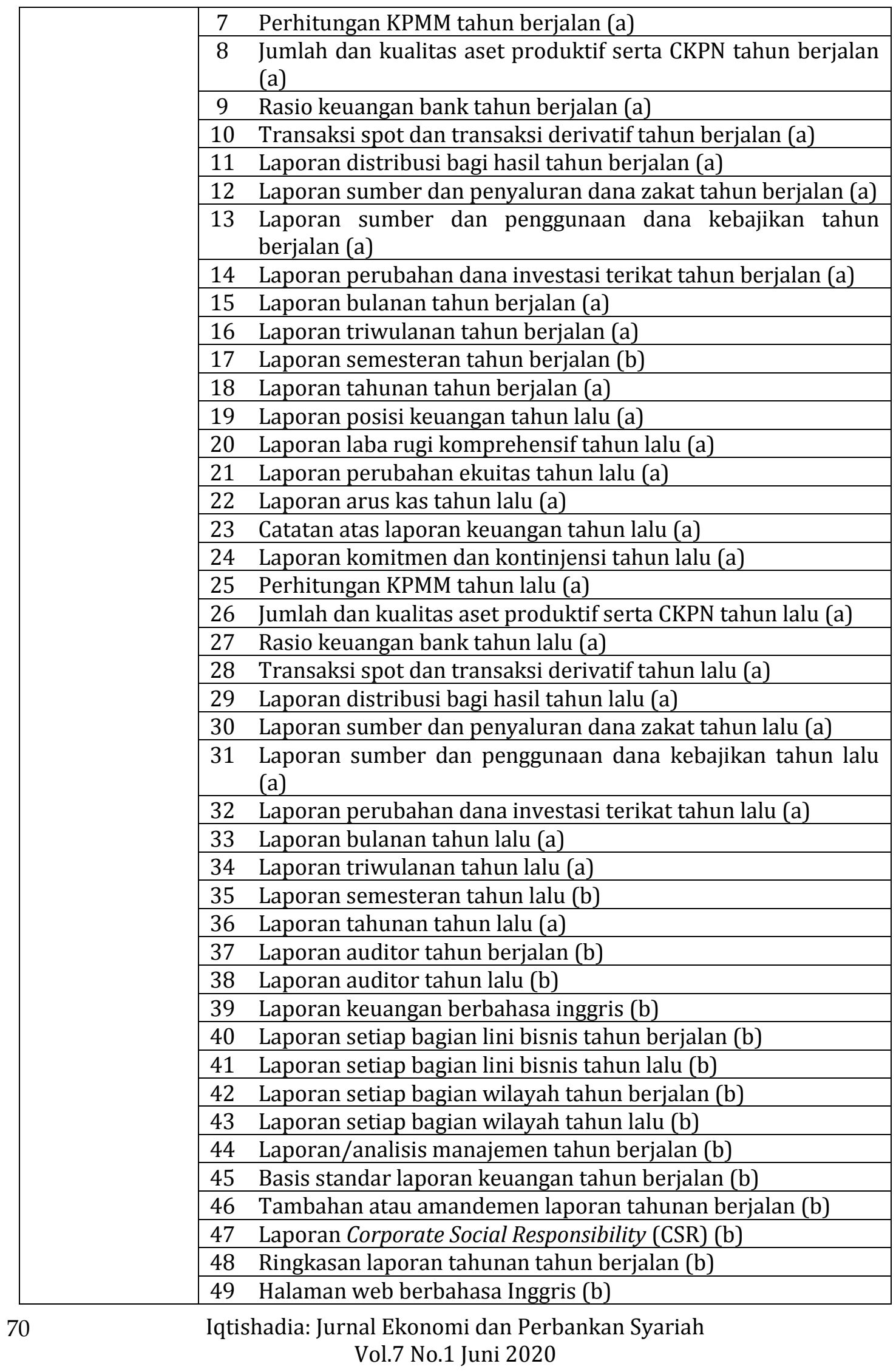


Analisis Penerapan Internet Financial Reporting (IFR) pada Bank Umum Syariah di Indonesia

\begin{tabular}{|c|c|c|}
\hline & 50 & Kebijakan akuntansi (b) \\
\hline & 51 & Informasi deviden (b) \\
\hline & 52 & Analisis risiko utama perusahaan (b) \\
\hline & 53 & Informasi perusahaan (b) \\
\hline & 54 & Laporan direksi (b) \\
\hline & 55 & Anggota direksi (b) \\
\hline & 56 & $\begin{array}{l}\text { Ringkasan data keuangan (min. } 5 \text { thn terakhir/menyesuaikan } \\
\text { tahun berdiri) (b) }\end{array}$ \\
\hline & 57 & 10 pemegang saham tertinggi tahun berjalan (b) \\
\hline & 58 & $\begin{array}{l}\text { Ringkasan rasio utama (min. } 5 \text { thn terakhir/menyesuaikan } \\
\text { tahun berdiri) (b) }\end{array}$ \\
\hline & 59 & Jalan singkat mencari informasi keuangan (b) \\
\hline & 60 & Tanda tangan auditor pada laporan tahun lalu (b) \\
\hline & 61 & Piagam komite audit (b) \\
\hline & 62 & Penghargaan yang diterima pada tahun berjalan (b) \\
\hline & 63 & Informasi pemegang saham (b) \\
\hline & 64 & Alamat perusahaan (b) \\
\hline & 65 & Informasi strategi perusahaan (b) \\
\hline & 66 & $\begin{array}{l}\text { Informasi tahun berjalan dapat dibedakan dengan tahun lalu } \\
\text { (b) }\end{array}$ \\
\hline & 67 & Informasi kepemilikan saham direksi (b) \\
\hline & 68 & Disclaimer/sangkalan (b) \\
\hline & 69 & Tanda tangan CEO dalam laporan (b) \\
\hline & 70 & Penjualan produk utama (b) \\
\hline & 71 & Informasi rapat umum tahunan (b) \\
\hline & 72 & Informasi rencana reinvestasi deviden (b) \\
\hline & 73 & Kode etik dan etika bagi direksi, petugas dan karyawan (b) \\
\hline & 74 & Indikator untuk menemukan informasi terkini secara cepat (b) \\
\hline & 75 & Informasi manager (min. identitas dan $C V$ eksekutif) (b) \\
\hline & 76 & Informasi proyeksi (b) \\
\hline & 77 & Informasi modal intelektual (b) \\
\hline & 78 & $\begin{array}{l}\text { Resolusi Rapat Umum Pemegang Saham (RUPS) tahun } \\
\text { berjalan (b) }\end{array}$ \\
\hline & 79 & Riwayat Harga Saham (b) \\
\hline & 80 & Siaran pers/berita terkini (b) \\
\hline & 81 & Prinsip pedoman perusahaan (b) \\
\hline \multirow{7}{*}{ 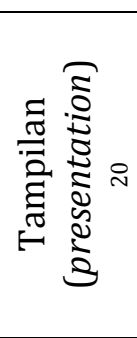 } & 1 & Waktu memuat website dibawah 10 detik \\
\hline & 2 & Laporan tahunan dalam format pdf \\
\hline & 3 & Hyperlink analis keuangan \\
\hline & 4 & Hyperlink dalam laporan tahunan \\
\hline & 5 & Link menuju homepage \\
\hline & 6 & Link menuju top hompage \\
\hline & 7 & Kemampuan mengunduh laporan \\
\hline
\end{tabular}

20 Ibid. 


\begin{tabular}{|c|c|c|}
\hline & 8 & Link menuju situs peta/sitemap \\
\hline & 9 & Kontak email langsung (umpan balik) yang tersedia \\
\hline & 10 & Data keuangan dalam format processable (contoh: excel) \\
\hline & 11 & Penggunaan teknologi multimedia \\
\hline & 12 & Situs peta/sitemap \\
\hline & 13 & Teks hyperlink \\
\hline & 14 & Hyperlink data pada sebuah situs web pihak ketiga \\
\hline & 15 & Memungkinkan mengubah format \\
\hline & 16 & Format laporan dapat digunakan untuk perhitungan \\
\hline & 17 & Mesin pencari (search engine) internal \\
\hline & 18 & Batasan jelas untuk laporan tahunan \\
\hline & 19 & Laporan tahunan dalam format html \\
\hline & 20 & Menu pull-down \\
\hline \multirow{11}{*}{ 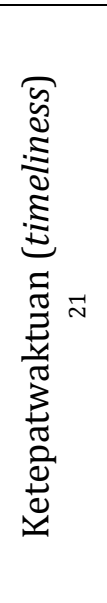 } & 1 & Tanggal terakhir pembaharuan website \\
\hline & 2 & Tahun terakhir pembaharuan website \\
\hline & 3 & Harga saham terbaru (saat ini) \\
\hline & 4 & Waktu pembaharuan khusus untuk data harga saham \\
\hline & 5 & Frekuensi pembaharuan laporan keuangan \\
\hline & 6 & Kalender kegiatan keuangan pada masa depan \\
\hline & & $\begin{array}{l}\text { Opsi pendaftaran email untuk pemberitahuan berita/siaran } \\
\text { terkini, dll }\end{array}$ \\
\hline & & $\begin{array}{l}\text { Informasi mengenai waktu untuk mendapat respon } \\
\text { pertanyaan melalui email dan pertanyaan online }\end{array}$ \\
\hline & & Webcast (siaran melalui website) \\
\hline & & Salinan berita peraturan terbaru \\
\hline & 11 & Laporan keuangan interim terbaru \\
\hline
\end{tabular}

Sumber: ${ }^{22} ;{ }^{23} ;{ }^{24}$

Populasi yang digunakan dalam penelitian ini adalah seluruh Bank Umum Syariah (BUS) di Indonesia yang tercatat dalam Statistik Perbankan Syariah (SPS) yang dikeluarkan oleh Otoritas Jasa Keuangan (OJK) per Desember 2016 dengan jumlah 13 BUS. Sedangkan teknik pengambilan sampel yang digunakan adalah metode purposive sampling dimana peneliti memberikan kriteria dalam penentuan sampel yang akan digunakan, yaitu:

1) Bank Umum Syariah yang memiliki website resmi yang aktif/dapat diakses dan tidak sedang dalam perbaikan.

2) Bank Umum Syariah yang melaksanakan IFR melalui website resminya.

${ }^{21}$ Omneya Abdelsalam and Ahmed El-Masry, "The Impact of Board Independence and Ownership Structure on The Timeliness of Corporate Internet Reporting of Irish-Listed Companies," Journal of Managerial Finance 34, no. 12 (2008), https://doi.org/10.1108/03074350810915842.

22 Otoritas Jasa Keuangan, "Salinan Surat Edaran Otoritas Jasa Keuangan Nomor 18/SEOJK.03/2015 Tentang Transparansi Dan Publikasi Laporan Bank Umum Syariah Dan Unit Usaha Syariah."

${ }^{23}$ Khan and Ismail, "The Level of Internet Financial Reporting of Malaysian Companies."

${ }^{24}$ Abdelsalam and El-Masry, "The Impact of Board Independence and Ownership Structure on The Timeliness of Corporate Internet Reporting of Irish-Listed Companies." 
Analisis Penerapan Internet Financial Reporting

(IFR) pada Bank Umum Syariah di Indonesia

Jenis data yang digunakan dalam penelitian ini adalah data sekunder karena data tersebut diperoleh secara tidak langsung melalui media perantara. ${ }^{25}$ Data tersebut berupa keterangan/informasi keuangan dan nonkeuangan yang bersumber dari website resmi masing-masing BUS. Alamat website masing-masing BUS diambil dari statistik data alamat BUS oleh OJK dan melalui bantuan search engine.

Setelah data dikumpulkan, maka tahapan selanjutnya adalah menganalisis data. Waktu penelitian untuk melakukan pengamatan penerapan praktik IFR pada BUS ini dilakukan selama bulan Februari 2020 dengan menggunakan laporan keuangan tahun 2016-2018 sebagai dasar tahun. Pemilihan tahun 2016 digunakan karena beberapa item variabel isi pada penelitian ini mengacu pada Peraturan Otoritas Jasa Keuangan Nomor 32/POJK.03/2016, sedangkan pemilihan tahun 2018 digunakan dengan alasan bahwa hampir belum ada bank yang mengungkapkan laporan keuangan tahunan pada tahun 2019 karena laporan publikasi tahunan pada situs web bank wajib diungkapkan paling lambat 4 (empat) bulan setelah akhir tahun buku. Selain itu agar dapat dilihat perbandingan serta perkembangan penerapan praktik IFR berdasarkan variabel isi pada BUS setiap periodenya. Sedangkan untuk penerapan praktik IFR berdasarkan variabel tampilan dan ketepatwaktuan diamati hanya pada tahun 2020.

Teknik analisis data yang digunakan dalam penelitian ini dilakukan dengan cara scoring. Pada teknik scoring ini tidak dibedakan bobot untuk setiap item pengungkapan penerapan praktik IFR pada 13 BUS. tahapan-tahapan dalam menganalisis data pada penelitian ini menjadi 4 yaitu: ${ }^{26}$

1. Memberikan skor untuk setiap item variabel yang diungkapkan melalui website bank, jika suatu item diungkapkan, maka akan diberikan skor satu (1) dan jika tidak diungkapkan akan diberikan skor nol (0).

2. Skor yang diperoleh bank pada ketiga variabel dijumlahkan untuk mendapatkan total skor pengungkapan masing-masing bank.

3. Menghitung skor kelengkapan pengungkapan (IFR Indeks) dengan menggunakan metode perhitungan yang cara perhitungannya sama seperti indeks pengungkapan pada umumnya (indeks wallace), yaitu dengan cara membagi total skor yang diperoleh dengan skor maksimal yang dapat diperoleh bank apabila mengungkapkan keseluruhan item. ${ }^{27}$

$$
\text { IFR Indeks }=\frac{\sum \text { skor yang diperoleh perusahaan }}{\sum \text { skor maksimal }}
$$

Skor maksimal yang akan diperoleh perusahaan merupakan total item indikator dari ketiga variabel penelitian yang berjumlah 274 item. Dengan rumus perhitungan tersebut, maka semakin banyak item pengungkapan yang disajikan akan semakin tinggi pula skor IFR yang diperoleh.

\footnotetext{
25 Nur Indrianto and Bambang Soepomo, Metodologi Penelitian Bisnis Untuk Akuntansi Dan Manajemen, 1st ed. (Yogyakarta: BPFE, 2011).

${ }^{26}$ Rizqiyah and Lubis, "Penerapan Internet Financial Reporting (IFR) Pada Bank Umum Syariah Di Indonesia."

${ }^{27}$ Khan and Ismail, "The Level of Internet Financial Reporting of Malaysian Companies."

Iqtishadia: Jurnal Ekonomi dan Perbankan Syariah 
4. Melakukan eksplorasi terhadap hasil penelitian sesuai dengan hasil yang dipaparkan pada penelitian terdahulu, lalu memberikan kesimpulan secara umum dari hasil penelitian.

\section{HASIL DAN PEMBAHASAN}

Perbankan syariah sebagai entitas syariah dalam melakukan pengungkapannya memiliki kewajiban untuk menyampaikan informasi yang memadai bagi penggunanya, karena ia harus dioperasikan sesuai dengan prinsip-prinsip syariah. Selain itu Bank Umum Syariah terikat dengan Peraturan Bank Indonesia Nomor 11/33/PBI/2009 tentang Pelaksanaan Good Corporate Governance bagi Bank Umum Syariah dan Unit Usaha Syariah. Dalam rangka melakukan transparansi tersebut. BUS dapat menyediakan informasi keuangan maupun nonkeuangan melalui berbagai media salah satunya melalui website resmi perusahaan atau biasa disebut Internet Financial Reporting (IFR). Oleh karena itu pada penelitian ini akan dilihat sejauh mana pengungkapan informasi keuangan dan nonkeuangan yang dilakukan oleh Bank Umum Syariah dengan IFR.

Hasil perhitungan skor IFR keseluruhan variabel penelitian dari 13 BUS berdasarkan pengamatan yang telah dilakukan oleh peneliti selama bulan Februari 2020 tersaji pada Grafik 1 dan lebih rinci pada tabel 2 Dari data tersebut diketahui bahwa skor yang diraih oleh masing-masing BUS memiliki nilai yang hampir setara. Tidak terdapat selisih skor yang signifikan di antara 13 bank yang dijadikan sampel penelitian.

\section{Grafik 1. Skor IFR BUS Keseluruhan}

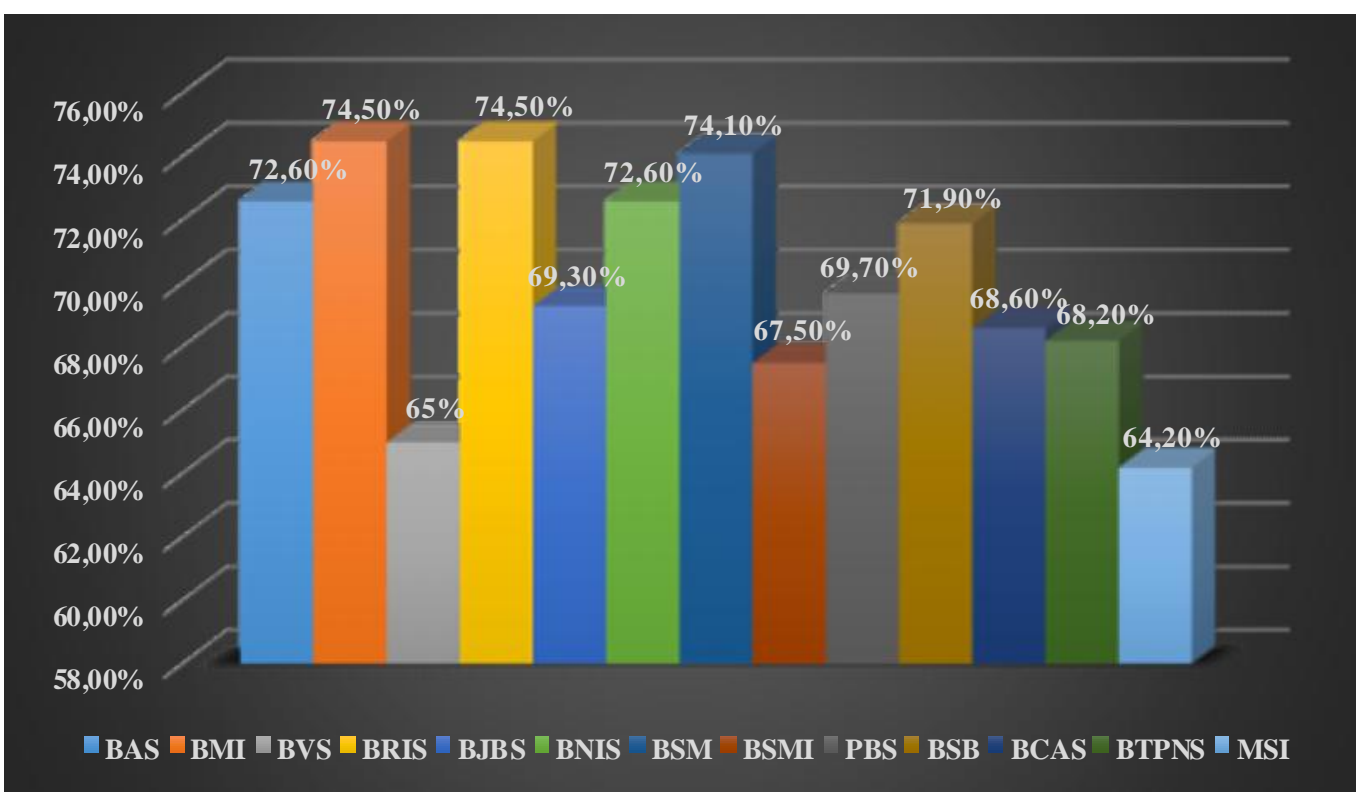

Sumber: Data diolah oleh penulis

Berdasarkan grafik 1 di atas, dapat dilihat bahwa nilai tertinggi dari hasil perhitungan skor IFR diraih oleh Bank Muamalat Indonesia (BMI) dan Bank BRI Syariah (BRIS) dengan skor sebesar 74,5\% atau dengan jumlah pengungkapan sebanyak 204 item. Hal ini dirasa wajar, karena BMI dan BRIS yang saat ini statusnya telah menjadi perusahaan Tbk dan dituntut untuk lebih transparan dalam melaporkan kondisi perusahaan demi kepentingan para pemegang saham dalam mengambil keputusan investasi serta menarik perhatian investor. Sementara nilai terendah diraih oleh Maybank 74 Iqtishadia: Jurnal Ekonomi dan Perbankan Syariah 
Analisis Penerapan Internet Financial Reporting (IFR) pada Bank Umum Syariah di Indonesia

Syariah Indonesia (MSI) dengan skor sebesar 64,2\% atau sebanyak 176 item pengungkapan. Untuk rincian hasil perolehan skor IFR pada masing-masing BUS sendiri akan disajikan dalam tabel 2 berikut.

Tabel 2 Hasil Perolehan Skor IFR Bank Umum Syariah

\begin{tabular}{|c|c|c|c|c|c|c|c|c|c|}
\hline \multirow[t]{2}{*}{ No } & \multirow{2}{*}{$\begin{array}{l}\text { Kode } \\
\text { Bank }\end{array}$} & \multicolumn{2}{|c|}{ Isi } & \multicolumn{2}{|c|}{ Tampilan } & \multicolumn{2}{|c|}{ Ketepatwaktuan } & \multicolumn{2}{|c|}{ Skor IFR } \\
\hline & & Item & $\%$ & Item & $\%$ & Item & $\%$ & Item & $\%$ \\
\hline \multicolumn{2}{|c|}{ Total Item } & 243 & $100 \%$ & 20 & $100 \%$ & 11 & $100 \%$ & 274 & $100 \%$ \\
\hline 1 & BAS & 185 & $76 \%$ & 12 & $60 \%$ & 2 & $18 \%$ & 199 & $72,6 \%$ \\
\hline 2 & BMI & 193 & $79 \%$ & 10 & $50 \%$ & 1 & $9 \%$ & 204 & $74,5 \%$ \\
\hline 3 & BVS & 166 & $68 \%$ & 10 & $50 \%$ & 2 & $18 \%$ & 178 & $65 \%$ \\
\hline 4 & BRIS & 188 & $77 \%$ & 12 & $60 \%$ & 4 & $36 \%$ & 204 & $74,5 \%$ \\
\hline 5 & BJBS & 175 & $72 \%$ & 12 & $60 \%$ & 3 & $27 \%$ & 190 & $69,3 \%$ \\
\hline 6 & BNIS & 182 & $75 \%$ & 15 & $75 \%$ & 2 & $18 \%$ & 199 & $72,6 \%$ \\
\hline 7 & BSM & 188 & $77 \%$ & 12 & $60 \%$ & 3 & $27 \%$ & 203 & $74,1 \%$ \\
\hline 8 & BSMI & 174 & $72 \%$ & 9 & $45 \%$ & 2 & $18 \%$ & 185 & $67,5 \%$ \\
\hline 9 & PBS & 179 & $74 \%$ & 11 & $55 \%$ & 1 & $9 \%$ & 191 & $69,7 \%$ \\
\hline 10 & BSB & 184 & $76 \%$ & 11 & $55 \%$ & 2 & $18 \%$ & 197 & $71,9 \%$ \\
\hline 11 & BCAS & 177 & $73 \%$ & 9 & $45 \%$ & 2 & $18 \%$ & 188 & $68,6 \%$ \\
\hline 12 & BTPNS & 173 & $71 \%$ & 12 & $60 \%$ & 2 & $18 \%$ & 187 & $68,2 \%$ \\
\hline 13 & MSI & 163 & $67 \%$ & 11 & $55 \%$ & 2 & $18 \%$ & 176 & $64,2 \%$ \\
\hline \multicolumn{2}{|c|}{ Rata-rata } & 179 & $74 \%$ & 11,23 & $56 \%$ & 2,15 & $20 \%$ & 192,4 & $70,2 \%$ \\
\hline
\end{tabular}

Sumber: Data diolah oleh penulis

Dari tabel 4.2 di atas, diketahui bahwa hasil perolehan skor IFR BUS berada pada rentang 64,2\% - 74,5\%. Hasil ini memang belum dapat dikategorikan sebagai hal yang memuaskan atau tidak karena belum ada ketentuan mengenai hal tersebut. Namun jika dilihat dari jumlah pengungkapan BUS yang telah menyajikan sebagian besar item pengujian ditambah dengan temuan-temuan lain yang akan dibahas pada sub bab selanjutnya, dapat dikatakan bahwa informasi yang diungkapkan oleh BUS telah cukup memadai.

Selain itu, dari tabel 4.2 di atas diketahui bahwa rata-rata skor IFR yang diraih BUS adalah sebesar 70,2\% $(192,4)$. Hasil ini merupakan kabar baik bagi industri perbankan syariah dimana mereka berhasil meraih skor IFR lebih dari 50\% pada saat belum tersedia peraturan khusus di Indonesia mengenai tata cara penyajian informasi perusahaan melalui website. Pada saat ini, OJK sendiri masih berada pada tahap penyusunan konsep dan rancangan mengenai hal tersebut. Selain itu, rancangan peraturan tersebut belum mencakup industri perbankan syariah karena hanya ditujukan untuk mengatur situs web emiten atau perusahaan publik Indonesia. Akan tetapi, BUS sangat terbantu dengan kehadiran Peraturan 0JK Nomor 32/POJK.03/2016 tentang Perubahan Atas Peraturan Otoritas Jasa Keuangan Nomor 6/POJK.03/2015 tentang Transparansi dan Publikasi Laporan Bank yang telah disebutkan sebelumnya.

Setelah dilakukan penelitian mengenai 3 (tiga) variabel pada seluruh BUS dan dilakukan analisis data pada masing-masing variabel yang diujikan. Maka selanjutnya dapat dilihat peringkat pada 13 BUS sesuai dengan skor IFR keseluruhan yang telah 
diperoleh. Hasil tersebut dapat dilihat pada tabel 4.9 yang menunjukkan urutan peringkat BUS dalam menerapkan praktik IFR mulai dari skor tertinggi hingga terendah.

Dari tabel 3 di bawah, dapat dilihat peringkat pertama skor IFR tertinggi pada BUS saat ini diraih oleh PT. Bank Muamalat Indonesia dan PT. Bank BRISyariah dengan jumlah pengungkapan 204 item atau dengan skor IFR sebesar 74,5\%. Urutan kedua dengan selisih 1 item pengungkapan ditempati oleh PT. Bank Syariah Mandiri dengan skor 74,1\% dan diikuti oleh PT. Bank BNI Syariah, PT. Bank Aceh Syariah, PT. Bank Syariah Bukopin, dan PT. Bank Panin Dubai Syariah yang menempati urutan 3, 4 dan 5. Sedangkan urutan terakhir ditempati oleh PT. Maybank Syariah Indonesia yang kini telah berganti nama menjadi PT. Bank Net Indonesia Syariah dengan skor 64,2\%.

Tabel 3. Peringkat Skor IFR BUS di Indonesia

\begin{tabular}{|llll|}
\hline Peringkat & Nama Bank & Skor IFR & Jml Item \\
\hline 1 & $\begin{array}{l}\text { PT. Bank Muamalat Indonesia } \\
\text { PT. Bank BRISyariah }\end{array}$ & $74,5 \%$ & 204 \\
\hline 2 & PT. Bank Syariah Mandiri & $74,1 \%$ & 203 \\
\hline 3 & $\begin{array}{l}\text { PT. Bank BNI Syariah } \\
\text { PT. Bank Aceh Syariah }\end{array}$ & $72,6 \%$ & 199 \\
\hline 4 & PT. Bank Syariah Bukopin & $71,9 \%$ & 197 \\
\hline 5 & PT. Bank Panin Dubai Syariah & $69,7 \%$ & 191 \\
\hline 6 & PT. Bank Jabar Banten Syariah & $69,3 \%$ & 190 \\
\hline 7 & PT. BCA Syariah & $68,6 \%$ & 188 \\
\hline 8 & PT. Bank Tabungan Pensiunan & $68,2 \%$ & 187 \\
\hline 9 & Nasional Syariah & & \\
\hline 10 & PT. Bank Mega Syariah & $67,5 \%$ & 185 \\
\hline 11 & PT. Bank Victoria Syariah & $65,0 \%$ & 178 \\
\hline
\end{tabular}

Sumber: Data diolah oleh penulis

Dengan adanya peringkat di atas, diharapkan setiap bank dapat mengetahui bagaimana kualitas dan kuantitas kegiatan pengungkapan informasi yang dimiliki perusahaan baik keuangan maupun nonkeuangan dalam website resmi yang dimilikinya atau yang biasa disebut dengan istilah Internet Financial Reporting (IFR). Dengan begitu, perusahaan dapat meningkatkan ataupun mempertahankan kualitas yang telah diraihnya. Hal tersebut berkesinambungan dengan teori yang digunakan, yaitu teori stakeholder dan teori sinyal. Dimana dikatakan dalam teori stakeholder bahwa teori ini bertujuan untuk membantu manajer perusahaan dalam upaya peningkatan nilai kegiatan mereka dan meminimalkan kerugian bagi para pemangku kepentingan. Sedangkan teori sinyal digunakan sebagai dasar menguji informasi yang terkandung dalam peristiwa pengungkapan IFR.

\section{PENUTUP}

Kurang lebih ada 8 BUS yang berhasil mempertahankan dan meningkatkan skornya. Skor terbesar yang di peroleh dalam variabel isi adalah 80\% yang didapatkan oleh BMI, BRIS, dan BSM pada tahun 2018, sedangkan penelitian yang dilakukan oleh ${ }^{28}$ skor

${ }^{28}$ Rizqiyah and Lubis, “Penerapan Internet Financial Reporting (IFR) Pada Bank Umum Syariah Di Indonesia."

76

Iqtishadia: Jurnal Ekonomi dan Perbankan Syariah

Vol.7 No.1 Juni 2020 
Analisis Penerapan Internet Financial Reporting

(IFR) pada Bank Umum Syariah di Indonesia

tertinggi pada variabel isi didapatkan oleh BNIS dengan skor 68\%. Selain itu terjadi peningkatan kurang lebih sebesar 10\% dimana pada penelitian ini 10 dari 13 bank atau $77 \%$ dari sampel penelitian berhasil menyajikan item pengungkapan dengan skor $70 \%$ $79.9 \%$.

Dalam pengamatan yang dilakukan, diketahui bahwa masih ada 2 BUS yang menggunakan item indikator tampilan dengan skor berkisar 40\% - 49.9\%, yaitu BSMI dan BCAS. Meskipun skor tertinggi mencapai skor 75\% atau setara dengan 15 dari 20 item pengungkapan yang diujikan, namun skor tersebut hanya diperoleh oleh satu bank, yaitu BNIS. Sementara sisanya menyajikan item indikator berkisar antara 50\% - 60\%. Hasil ini tidak berbeda jauh jika dibandingkan dengan hasil penelitian ${ }^{29}$ yang menunjukkan nilai tertinggi yang mencapai $70 \%$ yang diraih oleh BSM, sedangkan sisanya berkisar antara $50 \%-65 \%$.

Hasil pengujian pada variabel ketepatwaktuan menunjukkan hasil yang kurang memuaskan, perbedaan yang nampak hanya terletak pada harga saham terbaru dan waktu pembaharuan khusus untuk data harga saham yang berhasil diungkapkan oleh BRIS. Hal tersebut disebabkan karena pada tahun 2018 BRIS berhasil IPO dan menjual sahamnya di Bursa Efek Indonesia (BEI). Dengan kondisi tersebut BRIS memperoleh nilai tertinggi dengan skor mencapai $36 \%$ atau sebanyak 4 dari 11 item yang diujikan. Hasil tersebut jauh lebih baik dibandingkan hasil penelitian ${ }^{30}$ yang menyatakan bahwa skor tertinggi yang diraih 9 BUS hanya mencapai 18\%. Sedangakan sisanya mendapatkan skor $9 \%$.

\section{DAFTAR PUSTAKA}

Abdelsalam, Omneya, and Ahmed El-Masry. "The Impact of Board Independence and Ownership Structure on The Timeliness of Corporate Internet Reporting of IrishListed Companies." Journal of Managerial Finance 34, no. 12 (2008). https://doi.org/10.1108/03074350810915842.

Almilia, Luciana Spica. "Analisa Komparasi Indeks Internet Financial Reporting Pada Website Perusahaan Go Publik Di Indonesia.” Seminar Nasional Aplikasi Teknologi Informasi 2009, 2009.

—. "Faktor-Faktor Yang Mempengaruhi Pengungkapan Sukarela 'Internet Financial and Sustainability Reporting." Jurnal Akuntansi Dan Auditing Indonesia 12, no. 2 (2008).

Indrianto, Nur, and Bambang Soepomo. Metodologi Penelitian Bisnis Untuk. Akuntansi Dan Manajemen. 1st ed. Yogyakarta: BPFE, 2011.

Insani, Taqiyah Dinda, and Noven Suprayogi. "Internet Financial Reporting: Studi Komparasi Bank Umum Syariah Di Indonesia Dan Malaysia." Jurnal Ekonomi Syariah Teori Dan Terapan 3 (2016). https://doi.org/10.20473/vol3iss201611pp886.

Jensen, Michael C. "Value Maximisation, Stakeholder Theory, and The Corporate Objective Function." Journal of Applied Corporate Finance 14, no. 3 (2001). https://doi.org/10.1111/1468-036X.00158.

Khan, Mohd Noor Azli Ali, and Noor Azizi Ismail. "The Level of Internet Financial

\footnotetext{
${ }^{29}$ Ibid.
}

30 Ibid. 
Reporting of Malaysian Companies." Asian Journal of Accounting and Governance 2, no. 1 (2011). https://doi.org/10.17576/ajag-2011-2-6539.

- "Users' Perceptions of Various Aspects of Malaysian Internet Financial Reporting." Journal of Organizational Management Studies 2012 (2012). https://doi.org/10.5171/2012.852558.

Lipunga, Andrew Munthopa. "Internet Financial Reporting in Malawi." International Journal of Business and Management 9, no. 6 (2014).

Narsa, I Made, and Fitri Fenti Pratiwi. "Internet Financial Reporting , Pengungkapan Informasi Website, Luas Lingkup Pelaporan Internet, Dan Nilai Perusahaan.” Jurnal Ekonomi Dan Keuangan 18, no. $80 \quad$ (2014). https://doi.org/10.24034/j25485024.y2014.v18.i2.152.

Otoritas Jasa Keuangan. "Salinan Surat Edaran Otoritas Jasa Keuangan Nomor 18/SEOJK.03/2015 Tentang Transparansi Dan Publikasi Laporan Bank Umum Syariah Dan Unit Usaha Syariah," 2015.

—. "Statistik Perbankan Syariah," 2019.

Pertiwi, Imanda Firmantyas Putri. "Kinerja Keuangan Dan Internet Financial Reporting Index (IFRI): Sebuah Studi Relevansi Pada Sektor Perbankan Syariah Di Kawasan ASEAN." Jurnal Ekonomi \& Perbankan Syariah 4, no. 1 (2017). https://doi.org/10.19105/iqtishadia.v4i1.1221.

Purba, Lizzcharly, Henny Medyawati, Widya Silfianti, and Budi Hermana. "Internet Financial Reporting Index Analysis: An Overview from the State Owned Enterprises in Indonesia." Journal of Economics, Business and Management 1, no. 3 (2013).

Rizqiyah, Ria Nur, and Ahmad Tarmizi Lubis. "Penerapan Internet Financial Reporting (IFR) Pada Bank Umum Syariah Di Indonesia." Jurnal Akuntansi Dan Kenangan Islam 5, no. 1 (2017). https://doi.org/10.35836/jakis.v5i1.14.

Saud, Ilham Maulana, Bustanul Ashar, and Peni Nugraheni. "Analisis Pengungkapan Internet Financial Reporting Perusahaan Asuransi-Perbankan Syariah Di IndonesiaMalaysia." Jurnal Media Riset Akuntansi, Auditing \& Informasi 19, no. 1 (2019). https://doi.org/10.25105/mraai.v19i1.3011. 